\title{
Desastres ambientais e impactos socioambientais: inundações no município de Itaóca- SP: Bacia Hidrográfica como unidade de planejamento e gestão de riscos
}

\author{
Environmental disasters and environmental impacts: floods in county Itaóca- SP: \\ Basin as a planning unit and risk management
}

\author{
Mara Eliana Graeff Dickel \\ Licenciada em Geografia \\ Mestre em Geografia e Geociências pela Universidade Federal de Santa Maria \\ Doutora em Geografia pelo Programa de Pós-Graduação em Geografia (UNESP, Rio Claro) \\ mara_dickel@yahoo.com.br
}

Manuel Baldomero Rolando Berríos Godoy Graduação em Geografia e História pela Facultad de Educación, Letras (FEL) de la Universidad de Chile, Mestre em Geografia pela Universidade Estadual Paulista, Doutor em Geografia Humana pela USP Professor Assistente do Departamento de Planejamento Territorial e Geoprocessamento do Campus de Rio Claro, SP, Brasil rolando@rc.unesp.br

\begin{abstract}
Resumo
A temática de desastres ambientais figura na centralidade das discussões no período da contemporaneidade. A recorrência destes eventos de ordem hidrometeorológica alerta para a necessidade de um realinhamento das linhas de pensamento, principalmente no que concerne à gestão de riscos e desastres. Nesse sentido, o presente artigo busca defender a importância da adoção de uma nova escala de análise e planejamento sobre a bacia hidrográfica, conforme delimitado na lei 12.608 de 10 de abril de 2012. Para tal, exemplificou-se a situação tomando por base o evento ocorrido no mês de janeiro de 2014, na região do Vale do Ribeira (SP) e, de forma mais expressiva, no município de Itaóca, o qual resultou em 23 óbitos, além de um impacto de ordem ambiental, estrutural e social imensurável. Reconhecemos, também, a dificuldade encontrada para a consecução deste realinhamento; no entanto, a consideramos imprescindível para esta efetiva mudança, a qual se tornou urgente e necessária.
\end{abstract}

Palavras-chave: Riscos, Gestão de Riscos, Bacia Hidrográfica, Vale do Ribeira.

\begin{abstract}
The environmental disasters theme figures in the centrer of the discussions in the contemporary period. The recurrence of these hydrometeorological order of events highlights the need for a realignment of lines of thought, especially with regard to risk management and disaster. In this sense, this article seeks to defend the importance of adopting a new scale of analysis and planning on the watershed, as defined in the law 12608 of 10 April 2012. To this end, exemplified is the situation while building on the event occurred in January 2014, in the Ribeira Valley region (SP) and, more significantly, in the municipality of Itaóca, which resulted in 23 deaths, as well as an impact on environmental, structural and social immeasurable. We also recognize the difficulty in achieving this realignment; however, we consider it essential to this effective change, which has become urgent and necessary. Keywords: risk, risk management, watershed, Ribeira Valley.
\end{abstract}

Keywords: Risk, Risk management, Watershed, Ribeira Valley. 


\section{BACIA HIDROGRÁFICA COMO UNIDADE DE PLANEJAMENTO E GESTÃO DE RISCOS}

A temática riscos e desastres emerge no cenário atual como uma questão crucial para os delineamentos da sociedade contemporânea, passando a receber atenção sistemática de pesquisadores e estudiosos nas últimas décadas. O número e a intensidade desses eventos têm aumentado consideravelmente se comparados com as décadas de 1960, 1970 e 1980. Segundo dados disponibilizados no Atlas Brasileiro de Desastres Naturais (1991-2012), os últimos vinte anos apresentaram um montante de 38.996 eventos, sendo que $73 \%$ do total foram registrados nos últimos 10 anos.

Desde a década de 1970, a Organização das Nações Unidas (ONU) vem executando ações para a mitigação e redução dos efeitos de eventos danosos, dentre as quais podemos destacar o papel da Estratégia Internacional para Redução de Desastres (International Estrategy for Disaster Reduction - ISDR), derivada da Década Internacional para a Redução de Desastres Naturais (International Decade for Natural Disaster Reduction - IDNDR), a qual objetivou, inicialmente, a problematização da temática e a implementação de medidas para redução de riscos e vulnerabilidades, promovendo uma maior participação pública no tratamento destas questões.

Assim, há diversas concepções adotadas nos estudos concernentes à ciência cindínica, nominada também por Cindinicologia, a qual é entendida como ciência que objetiva "estudar e limitar os riscos aos quais estão expostas as populações" (FAUGÈRES 1991, apud REBELO 2005, p.66). A Cindinicologia trouxe, arraigada a este campo, várias concepções, abordagens e direcionamentos, incorporando desde a noção do desastre enquanto exterioridade ameaçadora até a concepção de um sistema articulado que perpassa a vivência e as práticas de gestão (VEYRET, 2007). Em conformidade com o que apresenta o sociólogo alemão Ulrich Beck (2010), o conceito de risco figura centralmente, no século $\mathrm{XX}$, como um dos maiores componentes da estruturação das sociedades desenvolvidas.

No Brasil, os eventos severos são recorrentes e, conforme o já mencionado Atlas Brasileiro de Desastres Naturais, que abrange os períodos de 1991-2012, houve um aumento expressivo nas últimas décadas. Os dados apresentados pelo Atlas destacam a ocorrência e registro de 38.996 eventos no período de 1991-2012, sendo que 22\% desse total (8.515) foram registrados na década de 1990, e 56\% ocorreram na década de 2000 (21.741 eventos); já nos anos de 2010, 2011 e 2012, a proporção de eventos concentrados é de 22\%, ou seja, 8.740 registros (CEPED - UFSC, 2012).

No ano de 2013, conforme dados do IBGE (BRASIL, 2013), foram reportados 493 eventos que resultaram em 183 óbitos e 18.557.233 pessoas afetadas. Dessa forma, é condição essencial aos rumos da sociedade contemporânea uma ampla busca de soluções que possam alterar drasticamente este cenário. Cabe, neste momento, uma ressalva quando nos referimos ao aumento dos registros: 
analisando-os puramente, não podemos afirmar que houve um aumento efetivo dos mesmos, uma vez que são notórias as dificuldades estruturais do Sistema de Defesa Civil em cadastrar os eventos de forma sistemática, principalmente no período anterior ao SIDEC.

No que concerne aos aspectos referentes aos eventos adversos do estado de São Paulo, dados do Atlas Brasileiro de Desastres Naturais - Volume São Paulo - relatam a ocorrência de 1.427 eventos severos no período de 1991-2012. O Atlas ainda elucida um contexto bastante preocupante, visto que, dos 645 municípios do estado de São Paulo, 425 já registraram algum evento natural adverso (estiagem e seca, movimentos de massa, erosões, alagamentos, enxurradas, inundação, granizo, incêndios e geadas) pelo menos uma vez.

Desta forma, salienta-se a importância do planejamento, análise e proposição de medidas para a redução e mitigação dos riscos. É necessário, conforme Veyret (2007) destaca, a constituição de um processo de análise e gestão de cenários de risco, cuja atuação deve ser entendida enquanto formas de intervenções diversas que englobam formulação e implementação de políticas públicas, estratégias, ações e instrumentos de redução e controle de riscos, objetivando, então, o aumento da resiliência das populações e a redução das situações de vulnerabilidade (NARVÁEZ et al., 2009).

Evidenciamos, então, a grande dificuldade contida na efetiva realização de uma gestão de riscos prospectiva, principalmente quando se menciona os riscos ambientais associados a eventos hidrometeorológicos atípicos em bacias hidrográficas. Esse obstáculo ocorre, primeiramente, pela dificuldade da coleta de dados no tocante ao recobrimento espacial e temporal adequado da área, a confiabilidade dos dados e, além disso, a dificuldade existente na previsão de eventos atípicos com antecipação suficiente (NARVÁEZ et al., 2009).

Outro ponto de inflexão, quando tratamos da temática riscos associados a eventos hidrometeorológicos em bacias hidrográficas, reside na dificuldade contida na compreensão da dinâmica da paisagem e na inter-relação de seus elementos entendidos tanto individualmente como sistemicamente. Neste ponto, a bacia hidrográfica é uma importante unidade de análise principalmente quando nos referimos aos estudos de desastres ambientais, visto que a bacia hidrográfica, enquanto área preferencial para o planejamento, possibilita o entendimento da dinâmica natural daquele espaço em toda sua complexidade, com sistema natural bem definido que permite, então, um planejamento prospectivo frente aos riscos naturais.

Frente ao que foi apresentado, o presente artigo tem por objetivo incitar a discussão a respeito dos riscos e desastres naturais, suas ocorrências e formas de gestão, destacando, então, a bacia hidrográfica como unidade de análise e gestão do risco. Assim, a área analisada corresponde a Unidade de Gerenciamento de Recurso Hídrico Ribeira do Iguape e Litoral Sul (UGRHI-11), no litoral sul de São Paulo. Optou-se por esta delimitação geográfica em virtude dos constantes eventos que atingem a bacia, pois segundo dados disponibilizados pelo Programa Estadual de Desastres 
Naturais e Riscos Geológicos - cenário de referência 2012, a UGRHI 11 ocupa a $4^{\mathrm{a}}$ posição no quesito eventos registrados, com 240 ocorrências no período 2000-2011, e a segunda mais afetada no que concerne os impactos à população, tendo atenção especial o desastre ocorrido no município de Itaoca em janeiro do ano de 2014.

\section{PLANEJAMENTO AMBIENTAL E GESTÃo DE BACIAS HIDROGRÁFICAS}

A extensão de um território é visível quando manuseamos qualquer modo de representação espacial, como mapas, cartas ou cartogramas; no entanto, quando nos referimos à questão dos recursos naturais, estes não obedecem a limites político-administrativos, transpondo fronteiras e regiões, podendo estar inseridos em dois ou mais municípios, estados ou até mesmo países.

Juridicamente, cada território determina, dentro das possibilidades administrativas, a forma de gestão dos seus recursos naturais, mas no tocante à água na forma dos corpos hídricos, esta apresenta uma unidade de gestão diferenciada: a bacia hidrográfica. A bacia hidrográfica é reconhecida pela Geografia Física como a melhor unidade de análise desde o final dos anos 60, contudo, somente após a década de 1990 foi efetivamente incorporada pelos profissionais como pertencente à área das ciências ambientais (BOTELHO; SILVA, 2004).

Embora tenha se firmado na década de 1990, inúmeras ações bem-sucedidas, as quais tomaram a bacia hidrográfica como recorte, já haviam ocorrido anteriormente. No ano de 1616, o tratado que estabelecia princípios sobre a utilização do Rio Danúbio já utilizava a bacia hidrográfica como unidade de delimitação de ações. Posteriormente, no ano de 1851, o tratado estabelecido entre Brasil e Peru sobre a navegação do Rio Amazonas e também o tratado entre Brasil e República das Províncias Unidas do Rio da Prata, em 1928, são a prova estabelecida através do tempo, a qual evidencia que a gestão de bacias hidrográficas é efetiva em seus resultados (PORTO; PORTO, 2008).

A gestão dos recursos hídricos pautada no recorte da bacia hidrográfica se firmou efetivamente na reunião preparatória da Rio-92, através dos Princípios de Dublin, citando o Princípio n.1, o qual destaca que a gestão, para ser efetiva, deve ser integrada e abarcar todos os aspectos: físicos, sociais, econômicos e ambientais, visto que a interação destes interfere no uso dos recursos, bem como nas atividades de gestão e planejamento do espaço (PORTO; PORTO, 2008).

A crescente e precípua necessidade de novos delineamentos na gestão e regulação dos recursos hídricos culminou com o Projeto de Lei n. 2.249, o qual foi encaminhado ao Congresso Nacional no ano de 1991, resultando na Lei n. 9.433/97, conhecida como Lei das Águas, a qual define: a) adoção da bacia hidrográfica como unidade de planejamento; b) reconhecimento da água 
enquanto um bem econômico; c) usos múltiplos existentes e potenciais dos recursos; e d) incorporação de um sistema de gestão descentralizado e participativo (LUCHINI, 2000).

Tal unidade foi definida juridicamente com a implementação da Política Nacional de Recursos Hídricos, no ano de 1997, e com a atuação do Sistema Nacional de Gerenciamento dos Recursos Hídricos, pois, na medida em que a bacia hidrográfica passa a ser entendida enquanto unidade sistêmica e morfológica permite a compreensão e análise dos problemas ambientais, sendo adequada para o manejo e o planejamento de ações (MUSETTI, 1999).

A Lei n. 12.608, de 10 de abril de 2012, enquanto publicação jurídica mais recente na gestão de riscos, institui a Política Nacional de Proteção e Defesa Civil, o Sistema Nacional de Proteção Defesa Civil e o Conselho Nacional de Proteção Defesa Civil. Ainda, a referida legislação evidencia a necessidade de um trabalho articulado entre as três instâncias de poder: União, Estados e Municípios, utilizando-se de uma abordagem sistêmica e preventiva. Além de outras articulações, o texto da lei ainda define, em seu $3^{\circ}$ artigo, inciso IV "adoção da bacia hidrográfica como unidade de análise das ações de prevenção de desastres relacionados a corpos d'água".

Em conformidade com o que é explicitado por Santos (2004), a adoção da bacia hidrográfica enquanto unidade de análise justifica-se, pois a mesma é entendida enquanto um sistema natural, palco de interações físicas ocorridas em um conjunto de terras delimitado topograficamente e drenado pelo curso de água e seus afluentes. Também é uma unidade de análise que, em virtude de suas interações complexas e sistêmicas, pode ser facilmente interpretada.

A bacia hidrográfica é um elemento fundamental de análise no ciclo hidrológico, pois é uma área delimitada por um divisor de águas que separa as bacias subjacentes. Sendo útil para a captação natural da água através das superfícies das vertentes, ela é resultado da interação da água e de outros elementos naturais (topografia, vegetação e clima) com a interferência antrópica (TUCCI, 1997). Nas palavras de Yassuda (1993, p.8), “a bacia hidrográfica é o palco unitário da interação das águas com o meio físico, o meio biótico e o meio social, econômico e cultural". Segundo Botelho e Silva (2004), a bacia hidrográfica é entendida como

célula básica de análise ambiental, a bacia hidrográfica permite conhecer e avaliar seus diversos componentes e os processos e interações que nela ocorrem. A visão sistêmica e integrada do ambiente está implícita na adoção desta unidade fundamental (p.153).

Dessa forma, conforme salienta Christofoletti (1999), "as bacias hidrográficas começaram a ser focalizadas como unidades geomorfológicas fundamentais, tendo em vista o funcionamento integrado dos seus elementos" (p.12). Então, analisar e compreender as diversas interações entre elementos físicos, ambientais e sociais constitui-se como importante questão para o entendimento das dinâmicas dos riscos e dos desastres ambientais em bacias hidrográficas, pois os impactos não 
se dão de forma isolada; em verdade, são resultado da integração de diferentes usos da água e do solo.

Assim, a bacia hidrográfica assume uma condição de dualidade: de um lado, a realidade física; e, de outro, um campo de ação política, de gestão, tomada de decisões e partilha de responsabilidade. Esse contexto impôs a necessidade de cooperação de diferentes esferas administrativas, resultando em um novo arranjo institucional: os Comitês de Bacias Hidrográficas ${ }^{1}$ (CUNHA; COELHO, 2003).

O modelo de gestão das bacias hidrográficas inerente à legislação brasileira prima pelos princípios de co-manejo e descentralização nas tomadas de decisão, representando rearranjos institucionais realizados no sentido de gerir o espaço e os recursos, conciliando interesses, resolvendo conflitos e partilhando responsabilidades sobre os mesmos (CUNHA; COELHO, 2003).

Ainda, a gestão de bacias hidrográficas utiliza-se direta ou indiretamente de uma série de instrumentos que trazem discussões sobre as mesmas, a exemplo a Bacia Hidrográfica do Rio Ribeira do Iguape, pois ela conta com os seguintes instrumentos de gestão: Plano Diretor de Recursos Hídricos, Plano da Bacia Hidrográfica do Rio Ribeira do Iguape e Litoral Sul - UGRH11 (Unidade de Gerenciamento de Recurso Hídrico 11), Agenda 21 do Vale do Ribeira, Plano da Mesorregião do Vale do Ribeira e Guaraqueçaba; Plano do Consad (VR), Plano de Desenvolvimento Territorial Sustentável do Vale do Ribeira-Paraná e São Paulo, sendo a questão das vulnerabilidades socioambientais da área mencionada apenas nos três primeiros documentos.

\subsection{Interação recursos naturais e atividades antrópicas em bacias hidrográficas}

Entendida como unidade espacial de análise e gestão dos recursos hídricos, a bacia hidrográfica abarca usos múltiplos: irrigação, abastecimento, consumo, uso industrial, dentre outros. Na medida em que existem interferências na dinâmica da paisagem através da retirada e alteração do fluxo de matéria e energia do sistema, tem-se como resultado os impactos que, conforme já mencionando, não incorrem isoladamente, pois são o somatório de consequências de diferentes usos que produzem efeitos sinérgicos e amplos, resultando em impactos em toda a extensão da bacia hidrográfica.

Então, alterações antrópicas de qualquer ordem, em qualquer local da bacia hidrográfica, podem ocasionar impactos e desastres: o desmatamento e a retirada de mata ciliar, crescimento e impermeabilização das áreas urbanas, a alteração do fluxo e direção dos corpos hídricos através da

1 A Lei das Águas (lei 9.433/97), regulada pelo decreto n. 2.612/98, delimita regras para criação e funcionamento do comitê de bacia, os quais se formalizam como fórum de decisões através do modelo de gestão descentralizada e participativa. 
retilinização e canalização dos mesmos, práticas agrícolas e solo desprovido de cobertura vegetal são alguns dos exemplos que podem ser citados a respeito da intervenção humana em bacias hidrográficas e que podem resultar na ocorrência de riscos e desastres ambientais.

Em grande parte das situações, os fatores naturais (topografia, solo, geologia, clima e vegetação) e sua intervenção são o ponto inicial de inflexão, causadores dos desequilíbrios, os quais são agravados, a posteriori, em decorrência das intervenções antrópicas, que são fruto do manejo inadequado da paisagem urbana e rural (CUNHA, 2000). Para Castro et al. (2005, p. 30),

seja na cidade ou no campo, os processos atmosféricos, hidrológicos, sociais, políticoeconômicos e industriais produzem quadros conjunturais de riscos, com diferentes intensidades e níveis de exposição da sociedade, que reclama esforços para a mitigação de danos, regulamentação de usos e compensações financeiras, definição de investimentos, e, em outra instância, políticas e ações específicas contidas no planejamento e na gestão territorial.

A urbanização e a impermeabilização incorrem em diversos impactos para as bacias hidrográficas, uma vez que a vazão é ampliada em decorrência do aumento da capacidade de escoamento, deflagração do processo erosivo e de produção de sedimentos em virtude da falta de proteção das superfícies, da deterioração da qualidade da água, e estrutura urbana implantada sem análise e planejamento (VEDOVELLO; MACEDO, 2012). Outro ponto a ser observado, ressaltado por Tucci (2003), refere-se à questão da ocupação das áreas de várzea correlacionada à frequência de recorrência dos eventos; em geral, aqueles com maior poder aquisitivo tendem a dispor suas residências em locais mais seguros, enquanto a população com baixo poder aquisitivo passa a ocupar áreas mais vulneráveis.

A preservação das características originais da área através da manutenção das formas de relevo e da cobertura vegetal da área contribui para o retardamento do escoamento superficial, na medida em que este atinge uma velocidade menor se comparada às áreas impermeabilizadas, pois a água oriunda da precipitação atinge o leito do rio de forma contínua, mas de forma mais lenta, não alterando a vazão do mesmo (TUCCI, 2005).

A figura a seguir apresenta claramente o comportamento do escoamento superficial em dois cenários distintos: o primeiro, antes do processo de urbanização e impermeabilização do solo; e o segundo, após o processo de impermeabilização das áreas. Destacamos que este não é efetivamente o cenário encontrado na Bacia Hidrográfica em questão, visto que, em sua ampla maioria, são municípios com pequenas manchas urbanas, mas não se descarta a existência de interferências diretas, pois os corpos hídricos passam próximos ou até mesmo no meio das cidades.

A expansão da urbanização desconsiderando a regulamentação urbana, resulta, conforme Tucci e Mendes (2006), em quatro grandes problemas: a) expansão irregular sobre áreas de mananciais; b) aumento na produção de efluentes; c) resíduos e efluentes não tratados; d) 
impermeabilização do espaço urbano e canalização de corpos hídricos aumenta o processo erosivo e, consequentemente, assoreamento dos corpos de água, aumentando a magnitude e a frequência de ocorrência de inundações.

A intervenção humana sobre a paisagem, indiferente da sua condição urbana ou rural, resulta na ocupação e na transformação da superfície do terreno, podendo certamente causar alterações potencialmente danosas. A seguir, seguem representadas as áreas de várzea e seu comportamento em áreas urbanas e rurais, sendo o processo de urbanização um fator determinante para as alterações na vazão em comparação ao processo natural.

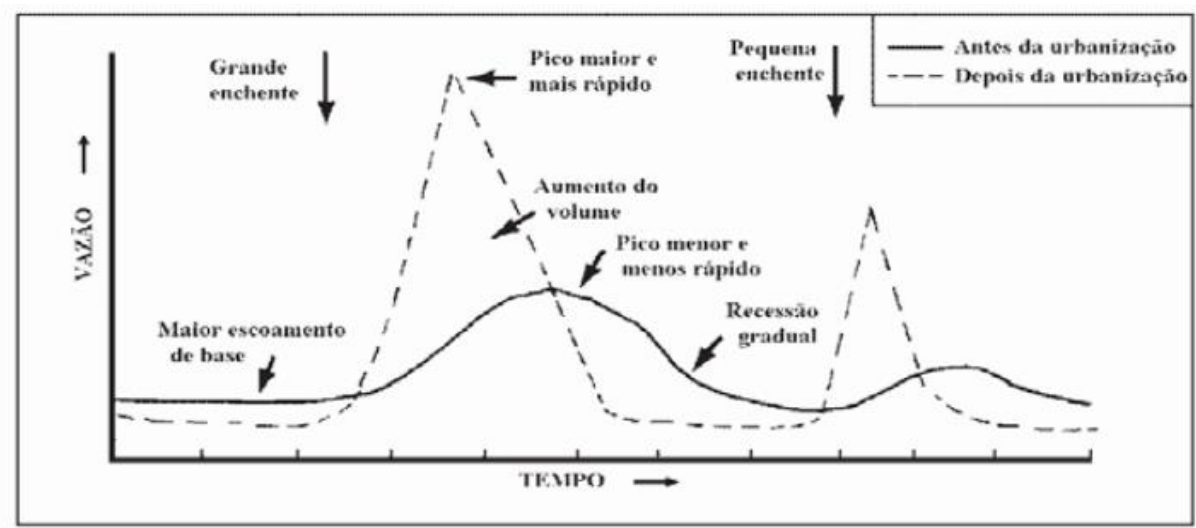

Figura 1 - Comportamento do escoamento superficial pré e pós-urbanização. Fonte: Tucci e Mendes (2006)

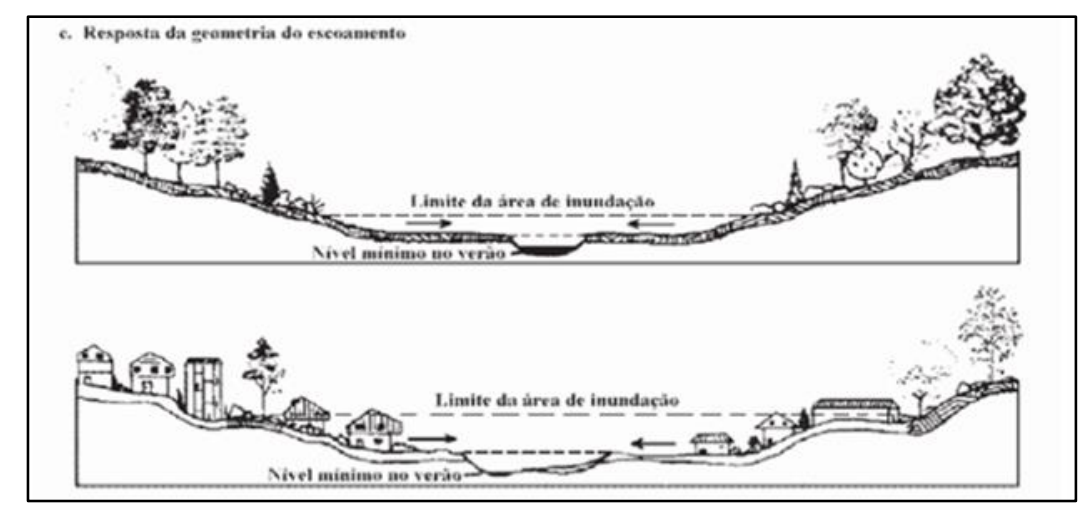

Figura 2 - Resposta Geométrica do Escoamento Superficial: alterações da área rural para urbana Fonte: Tucci e Mendes (2006)

Além disso, a ocorrência de chuvas intensas ou de longa duração contribuem para a saturação do solo, resultando no aumento do escoamento superficial, na medida em que a capacidade de infiltração passa a ser diminuida proporcionalmente. No que concerne à questão precipitação, Tucci (2003) destaca que as precipitações mais intensas são as denominadas precipitações orográficas ou convectivas, sendo geralmente concentradas em pequenas localidades, já as precipitações frontais atuam sobre grandes áreas, possibilitando a ocorrência de grandes inundações. 
No que concerne à questão cobertura do solo e supressão de vegetação com impactos em bacias hidrográficas, infere-se que a retirada das mesmas, deixando solo desnudo, traz grandes consequências a este sistema, pois ocorre um aumento de sedimentos erodidos, os quais são carreados para os cursos de água. A alteração da superfície da bacia tem impactos significativos, aumentando o escoamento superficial, resultando na alteração do comportamento do fluxo das águas com relação ao escoamento (direção e velocidade) e capacidade de infiltração. Conforme dados disponibilizados pela Organização das Nações Unidas (ONU), recomenda-se a manutenção mínima de $12 \mathrm{~m}^{2} /$ hab. de área verde, objetivando minimizar os impactos gerados pelo processo de urbanização.

A compreensão dos impactos ambientais enquanto movimento e processo conduz a uma concepção complexada das relações entre sociedade e natureza. Esta sistemática de análise dos impactos, sugerida por Morin (1996), infere a necessidade de incorporarmos a relação dialética pautada na simplificação e na complexificação. Enquanto a primeira consiste em selecionar o que, em tese, seria mais significativo, desconsiderando o incerto e o ambíguo, a complexação, por sua vez, considera a multiplicidade dos dados e informações, reconhecendo o ambíguo, o incerto, o variado e o variável.

Além desta visão horizontal de variáveis e elementos que caracterizam os impactos, torna-se urgente também a compreensão dos processos através de uma articulação escalar: da micro, da meso e da macroescalas de análise, facilitando a constituição de uma visão complexa e integrada dos processos e impactos ambientais (COELHO, 2006).

Todos estes contextos apresentados refletem as deficiências das políticas públicas de planejamento territorial. Tanto ao nos referimos à proposição de estudos e normativas quanto à fiscalização de sua efetiva implantação e execução, estas ações oportunizariam certamente a diminuição das fragilidades das comunidades em situação de vulnerabilidade.

\section{DEFINIÇÕES E ABRANGÊNCIA DO TERMO RISCO AMBIENTAL}

\subsection{Risco associado a bacias hidrográficas: o caso de Itaoca}

A questão riscos e desastres sempre figurou como papel de destaque nos compêndios da história da humanidade. São infinitas as referências históricas destes eventos que transitam desde eventos vulcânicos até secas e tsunamis, com diferentes ordens e magnitudes. Inúmeras são as manifestações que se sucedem no tempo e no espaço e que, embora mediante o desenvolvimento científico e tecnológico, ainda resultam em impactos nas mais diversas esferas: ambiental, social ou econômico. 
A delimitação conceitual de riscos e desastres ainda é uma questão indefinida, visto que várias são as possibilidades e discussões apresentadas. A definição proposta pela Organização das Nações Unidas para a Redução de Desastres (United Nations Disaster Relief Organization UNDRO) delimita o termo risco enquanto o grau de perdas previsto em virtude de um fenômeno adverso de ordem natural correlacionado à vulnerabilidade. Vedovello e Macedo (2012, p.20) definem o conceito de risco também em virtude das possíveis perdas, sejam elas humanas e/ou materiais, na ruptura de atividades econômicas ou danos de ordem ambiental, sendo resultado da interação de perigos naturais gerados ou não pelo homem, da vulnerabilidade e do dano potencial.

O termo "natural hazard" é uma expressão inglesa cuja interpretação é bastante diversa. A tradução deste termo foi objeto de estudo no colóquio realizado em 1990, na cidade de Paris, pela Association Geographique Française, no qual a expressão foi traduzida como "risques naturels", conforme os estudos apontados por Faugère no ano de 1990. Este colóquio incorporou os estudos a respeito do "risques naturels" na agenda de discussões da Geografia Física da França, que passou a incluir outros aspectos, também em decorrência do aumento dos eventos catastróficos ocorridos.

Almeida (2012) apresenta uma definição de que o mesmo é incerteza, exposição ao perigo, à perda e ao prejuízo tanto de ordem material quanto humana, não restringindo sua análise exclusivamente aos processos naturais, estendendo-os aos aspectos e intervenções antropogênicas.

Veyret (2007) delimita o conceito sob a ótica da contribuição da percepção do perigo, da possível ocorrência do evento danoso, ameaça sentida ou percebida pela sociedade. Esta autora ainda destaca o papel da intervenção antrópica neste processo, sendo os riscos potencialmente assumidos. É neste contexto que a análise, observação e identificação de áreas de risco são essenciais para a redução dos impactos decorrentes dos eventos adversos.

Quanto ao termo desastre, em conformidade com a definição elaborada pelo Banco de Dados Internacional de Desastres (Emergency Disaster Data Base EM-DAT), o mesmo deve ser entendido como grave perturbação da dinâmica e funcionamento da sociedade, englobando perdas de ordem ambiental, urbana e econômica. Vedovello e Macedo (2012) definem objetivamente desastre enquanto fenômeno ou perigo que atinja objetivamente a população causando alterações, perturbações e perdas.

No tocante aos aspectos episódicos, o Estado de São Paulo está sujeito à ocorrência de vários eventos adversos em virtude da combinação de fatores de ordem geológica, geomorfológica e climática, agravados pela intervenção antrópica. As inundações e enxurradas são fenômenos naturais associados à dinâmica da bacia hidrográfica e seus impactos diferem e distribuem-se conforme o local de ocorrência, sendo possivelmente mais impactantes em áreas urbanizadas.

A região sudeste do Brasil encontra-se suscetível à ocorrência de eventos extremos. Tal fato deve-se, em grande parte, pela combinação de fatores geológicos, geomorfológicos e climáticos, 
sob a interferência direta das ações antrópicas. Em conformidade com o que apresenta Marengo (2007), a região sudeste é reconhecida como uma área com regime pluviométrico intenso no período do verão, sendo atingida mais frequentemente por fenômenos denominados como Zona de Convergência do Atlântico Sul (ZCAS) e também por frentes frias.

Além das características climáticas, geológicas e geomorfológicas, a questão alteração antrópica figura no eixo central dos elementos desencadeadores de desastres ambientais, sendo o desastre uma condição potencialmente assumida na medida em que se modifica a dinâmica de um curso de água, que se impermeabiliza o solo, ou quando se realiza intervenções recorrentes em áreas urbanas.

Assim, as inundações e enxurradas, eventos extremos de ordem hidrometeorológica, conforme o Atlas Brasileiro de Desastres Naturais 1991- 2012, Volume São Paulo, possuem relação direta com o aumento das precipitações e são vinculadas, obviamente, com as modificações da paisagem urbana e rural. Estes eventos representam o que equivale a $68 \%$ dos registros de eventos adversos do estado de São Paulo, concentrando-se, respectiva e proporcionalmente, nos meses de janeiro, fevereiro, março e dezembro.

O grande impacto decorrente dos eventos de inundação e enchentes consiste nas consequências causadas a partir do momento em que o nível de água atinge a população. Neste sentido, Monteiro (2003) faz uma imprescindível reflexão e afirma, com base na obra de Gilbert White (1974), que a existência de um natural hazard se dá em função de um "ajustamento humano", destacando, assim, que as iniciativas do homem contribuem negativamente para tal cenário.

Nas palavras de Monteiro (2003, p. 8 e 9), “enchentes não seriam danosas se homem evitasse planícies inundáveis", além de que a atuação humana pode decisivamente contribuir para alterar as condições de regime a escoamento. Obviamente, não seremos extremistas ao afirmar que viver nesta situação é a opção mais confortável para a população; do contrário, esse contexto é o reflexo direto de um contexto ainda maior de carência de políticas de planejamento e gestão tanto do espaço urbano quanto do espaço rural.

A área de estudo da presente pesquisa consiste na Unidade de Gerenciamento de Recursos Hídricos 11- UGRHI-11, que corresponde à Bacia Hidrográfica do Ribeira do Iguape e Litoral Sul, a qual se estende a leste do estado do Paraná e a sudeste do Estado de São Paulo, localizada entre duas regiões metropolitanas: São Paulo e Curitiba. A bacia hidrográfica abrange uma área total de $25.681 \mathrm{~km}^{2}$, e um total de 32 municípios, sendo 23 pertencentes ao estado de São Paulo e o restante ao estado do Paraná. A referida área de estudo é a maior bacia costeira do estado e a única a desaguar no oceano. 


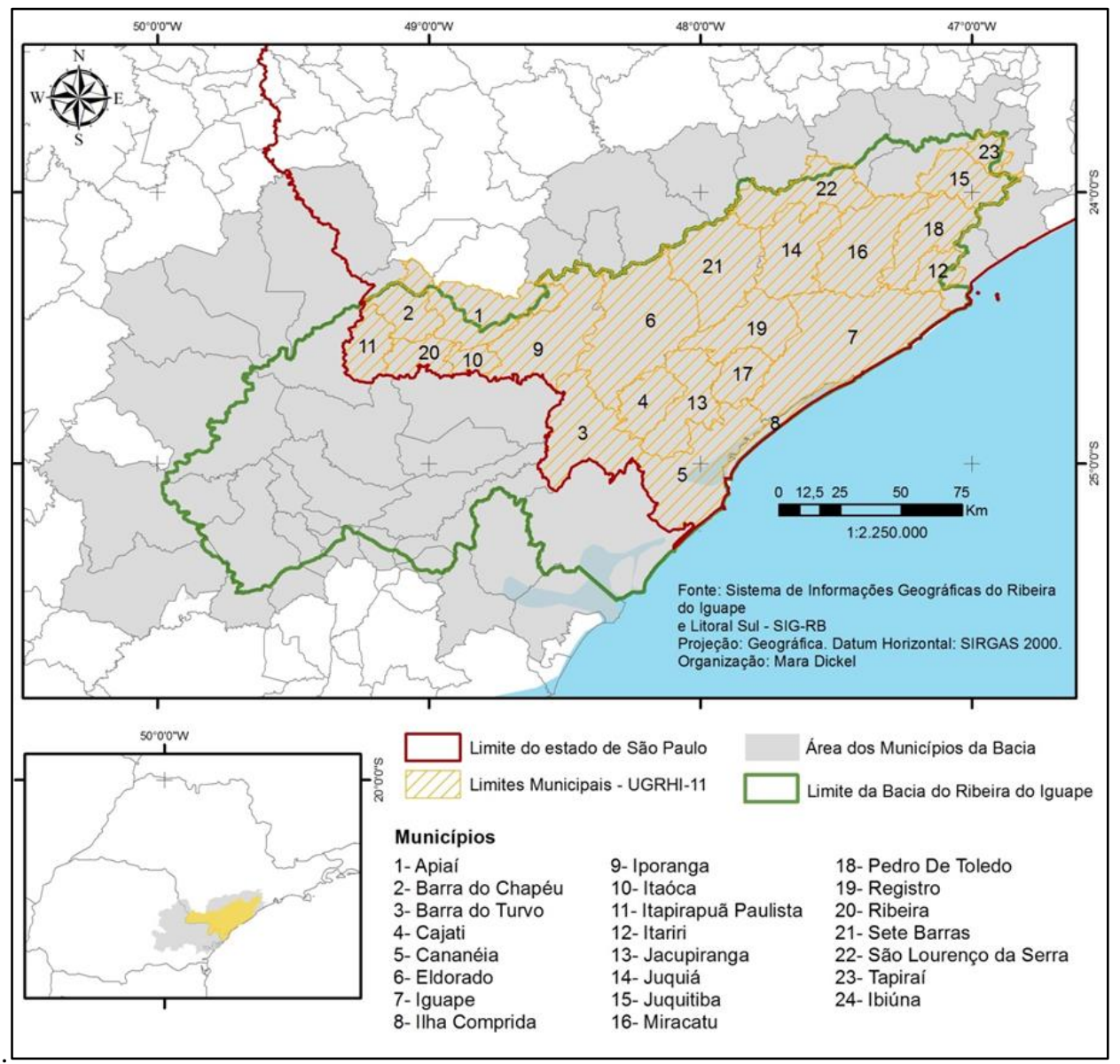

Figura 3 - Localização dos municípios da UGRHI - 11 Organizado pelo autor (2015)

A UGRHI-11 é a segunda região do estado em registros de eventos de inundação gradual e brusca, sendo a Mesorregião Metropolitana de São Paulo a mais afetada, seguida pela Mesorregião do litoral paulista. No período referente a 1991-2012, registrou-se 12 eventos (inundação gradual ou brusca em Eldorado), 12 eventos também em Registro, seguidos por Iguape com 10 eventos , Itariri e Barra do Turvo com 8 eventos cada um.

A Bacia Hidrográfica do Ribeira de Iguape e Litoral Sul é reconhecida pela sua diversidade, seja ela formada por elementos paisagísticos ou sociais. Considerada desde o ano de 1999 como patrimônio natural, socioambiental e cultural da humanidade pela United Nations Educational, Scientific and Cultural Organization (UNESCO), a área abriga a maior porção de mata atlântica remanescente e ecossistemas associados do Brasil, além de ter incorporado a sua área $40 \%$ das unidades de conservação do estado de São Paulo, tendo também a presença de comunidades tradicionais em seu território (CBR-RB-1, 2008).

No que concerne aos aspectos hidrológicos, a área da bacia em questão é caracterizada por uma vasta lista de afluentes do Rio Ribeira. Os principais rios da unidade são o Rio Ribeira do Iguape e seus afluentes: Acunguí, Capivari, Pardo, Turvo, Juquiá, São Lourenço, Jacupiranga, Itapirapuã, Una da Aldeia e Itariri. 
Outro ponto bastante relevante da área sob análise, quando mencionamos a recorrência de eventos extremos, consiste nos aspectos do relevo da área, o qual pode ser dividido em duas grandes morfoestruturas: Faixa de Dobramento do Atlântico e Depressão Tectônica do Baixo Ribeira. Ross (2002) propõe uma classificação de relevo tomando por base os sistemas ambientais da área: Sistema de Planície Costeira Cananéia-Iguape, Sistema de Terraços Fluviais do Rio Ribeira do Iguape, Unidade de Sistema de Colina e Morrotes na depressão tectônica do Baixo Ribeira, Unidade Sistema de Morros Escarpas da Serra do Mar e Paranapiacaba, e Unidade de Sistema de Morros em superfície de cimeira de Alto Ribeira.

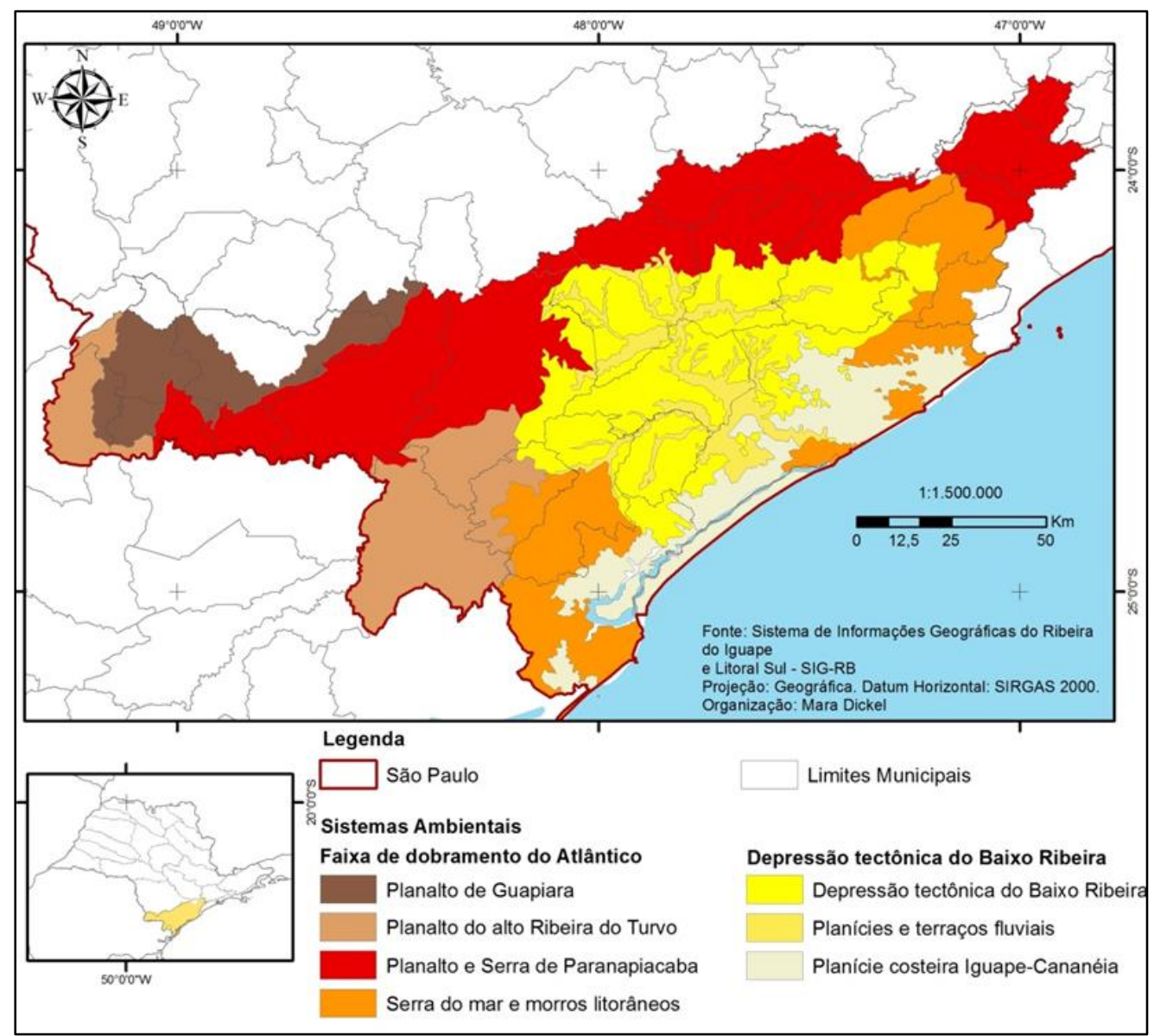

Figura 4 - Sistemas ambientais propostos por Ross (2002)

Organizado pelo autor (2015)

A presença de duas feições de relevo bem definidas, sendo uma com maiores amplitudes altimétricas, maior declividade e localizada mais para o interior da Bacia do Ribeira do Iguape, e que, por muitas vezes, há fatores climáticos que coincidem com as áreas que possuem maior média de precipitação. Já a segunda feição do relevo é caracterizada por sua baixa amplitude altimétrica, planícies sedimentares, terraços marinhos e fluviais que recebem o fluxo de água oriundo de eventos pluviométricos extremos, como pode ser visualizado no mapa a seguir. As maiores concentrações pluviométricas ocorrem nas áreas de maior amplitude altimétrica; desta forma, há um 
aumento no fluxo subsuperficial em direção às áreas mais baixas (as planícies), consequentemente, as áreas com maior recorrência de áreas de risco mapeadas.

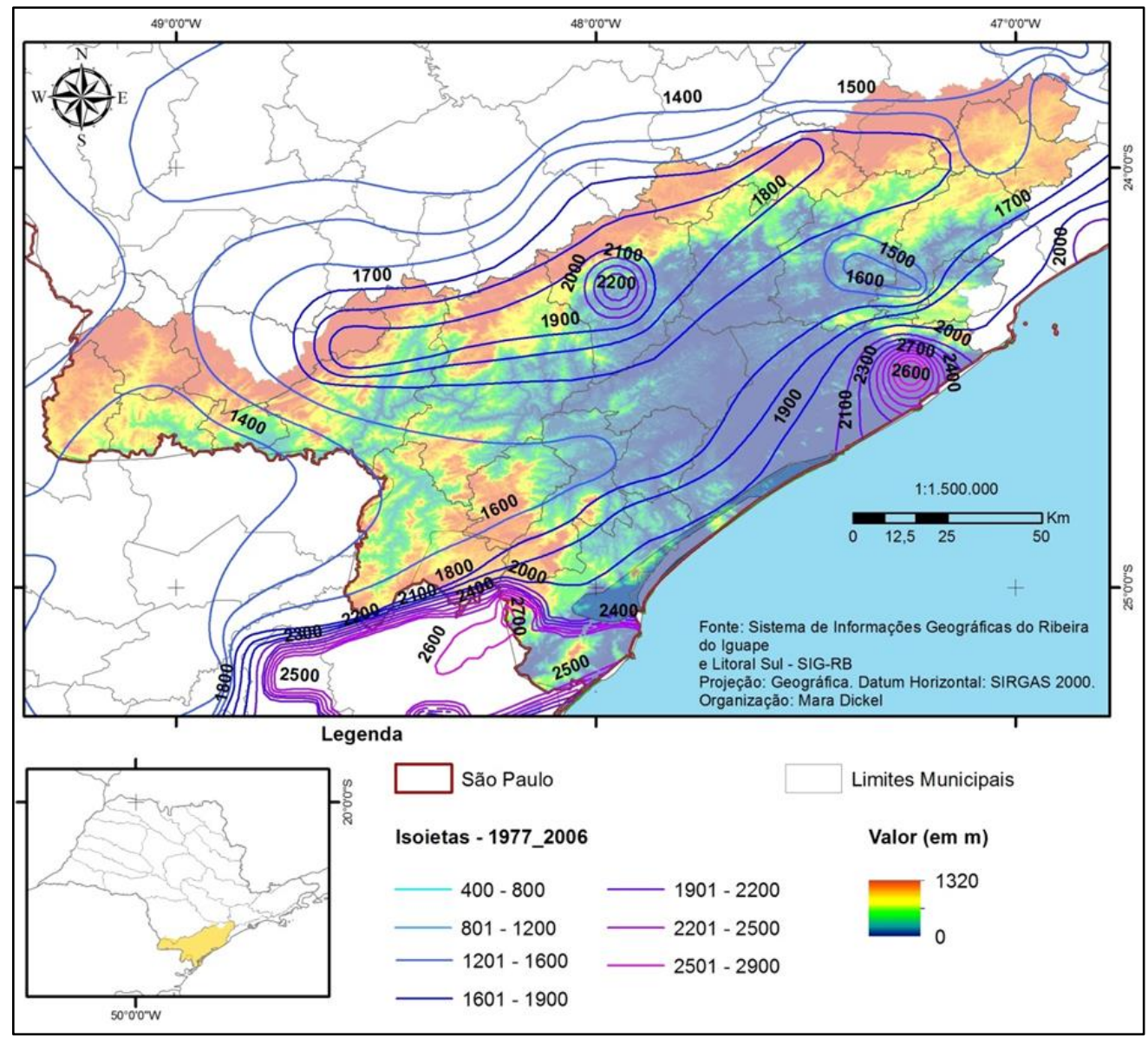

Figura 5 - Análise da precipitação frente à questão relevo na UGRHI 11 Organizado pelo autor (2015)

Sob o ponto de vista das condições potenciais para a geração de eventos de inundação e cheia, o Vale do Ribeira dispõe de características peculiares que o define como extremamente vulnerável. Primeiramente, podemos destacar as condições climáticas, altamente propensas à ocorrência de chuvas do tipo frontal, que caracteristicamente são eventos de grande intensidade e duração. Além disso, outra característica, que pode ser visualizada no cartograma anterior (figura 5), refere-se às características morfológicas, nas quais os cursos médio e superior do Ribeira, bem como de seus afluentes, percorrem vales encaixados e declividade elevada. Após Eldorado, o Rio Ribeira do Iguape assume as configurações de um rio de planície, atingindo declividades nulas. 
Tabela 1 - Situação da UGRHI 11 frente aos riscos - áreas mapeadas

\begin{tabular}{|c|c|c|c|c|c|c|c|c|c|c|}
\hline & 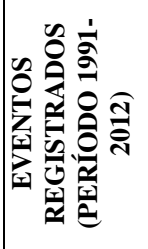 & 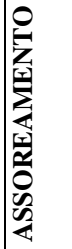 & 至 & 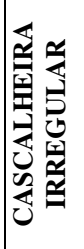 & 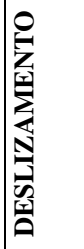 & 茪 & 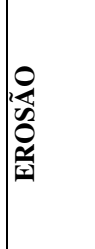 & 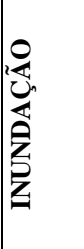 & 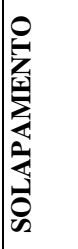 & 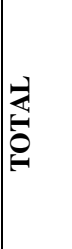 \\
\hline Apiaí & 3 & & & & 15 & 1 & & 9 & & 25 \\
\hline Barra do Chapéu & 3 & & 1 & & 2 & & & 6 & & 9 \\
\hline Barra do Turvo & 9 & & & & 7 & & $1 *$ & 5 & & 12 \\
\hline Cajati & 13 & & 2 & & 17 & 1 & & 13 & & 33 \\
\hline Cananéia & 5 & & 7 & & 1 & & $\begin{array}{c}1^{* *} \\
3^{* * * *}\end{array}$ & 2 & & 14 \\
\hline Eldorado & 16 & & & & 9 & & & 13 & 5 & 27 \\
\hline Iguape & 9 & & 6 & & & & $\begin{array}{c}1 * \\
1 * * *\end{array}$ & 16 & & 24 \\
\hline Ilha Comprida & 3 & 3 & & & & & $\begin{array}{c}1 * * \\
1 * * *\end{array}$ & 2 & & 7 \\
\hline Iporanga & 4 & & & & 9 & & & 3 & 1 & 13 \\
\hline Itaoca $* * * *$ & 1 & & & & & & & & 4 & 4 \\
\hline Itapirapuã Paulista & 2 & & & & 5 & & & 7 & 1 & 13 \\
\hline Itariri & 6 & & 1 & & 9 & & & 6 & 4 & 20 \\
\hline Jacupiranga & 10 & & & & 4 & & & 23 & & 27 \\
\hline Juquiá & 5 & & 1 & & 15 & & 1 & 7 & 2 & 26 \\
\hline Juquitiba & 3 & & & & 11 & & & 4 & 1 & 16 \\
\hline Miracatu & 5 & & & & 6 & & & 12 & & 18 \\
\hline Pariquera-Açu & 5 & & & 2 & 1 & & & 6 & & 9 \\
\hline Pedro de Toledo & 5 & & & & 5 & & & 9 & & 14 \\
\hline Registro & 12 & & & & 7 & & & 63 & & 70 \\
\hline Ribeira & 3 & & & & 5 & & & 7 & 1 & 13 \\
\hline São Lourenço da Serra & 1 & & & & 3 & & & 3 & & 6 \\
\hline Sete Barras & 11 & & & & 7 & & & 6 & 2 & 15 \\
\hline Tapiraí & 1 & & & & 3 & & & 2 & & 5 \\
\hline Total: 23 municípios & 39 & 3 & 18 & 2 & 141 & 2 & 1 & 224 & 21 & 408 \\
\hline
\end{tabular}

* erosão marginal, **erosão, ***erosão marinha, não conta o registro do evento de 2014.

Organizado pelo autor (2015)

Ao observarmos o cartograma anterior, bem como a tabela apresentada, podemos perceber um breve diagnóstico elaborado a respeito das áreas de risco no Vale do Ribeira, com destaque para o município de Registro, com 70 áreas mapeadas, sendo que, destas, 63 correspondem a áreas vulneráveis a eventos de inundação; em segundo plano, há o município de Cajati, com 33 áreas identificadas, e Jacupiranga e Eldorado, ambos com 27 áreas cada.

Conforme relatório apresentado pelo DAEE (2004), o estado de São Paulo encontra-se vulnerável à ocorrência de dois tipos de inundações: a primeira ocorre na bacia do Alto Tietê, atingindo uma área de 3,2\% do estado, afetando aproximadamente metade da população de São Paulo, e a segunda refere-se às inundações ocorridas na Bacia Hidrográfica do Rio Ribeira do Iguape. A exemplo deste contexto, podemos citar os dados disponíveis no Atlas do IBGE que atribui destaque a situação de Sete Barras, no ano de 2010, com 11 pessoas desabrigadas e 11.700 
pessoas afetadas; há também a situação de Eldorado, no ano de 2011, com 1.510 desabrigados e 14.000 pessoas afetadas pelas inundações e enchentes.

O Vale do Ribeira apresenta constantes eventos de grande impacto, a exemplo da enchente ocorrida no ano de 1997, denominada como "Enchente do Século" em virtude da grande proporção territorial atingida. O evento mencionado atingiu 11 municípios do Vale do Ribeira, desabrigando 15.440 pessoas, ocasionando três óbitos e impactos de todas as ordens.

A saber sobre este contexto, o Vale do Ribeira, representado pelo município de Itaoca, sofreu, em janeiro do ano de 2014, um evento de proporções catastróficas. No dia 12 de janeiro de 2014, precipitações extremas atingiram a bacia do Alto Ribeira, principalmente nas porções de maior altitude da área, resultando em eventos de deslizamento, corridas de massa e inundações bruscas. Salientamos que, conforme a imagem extraída do Satélite GOES, referente ao dia do evento, com horário de $23 \mathrm{~h}$, a chuva não ficou restrita a esta área do município de Itaoca, pois muitos outros municípios passaram a trabalhar em estado de atenção em virtude da elevação do leito dos rios.

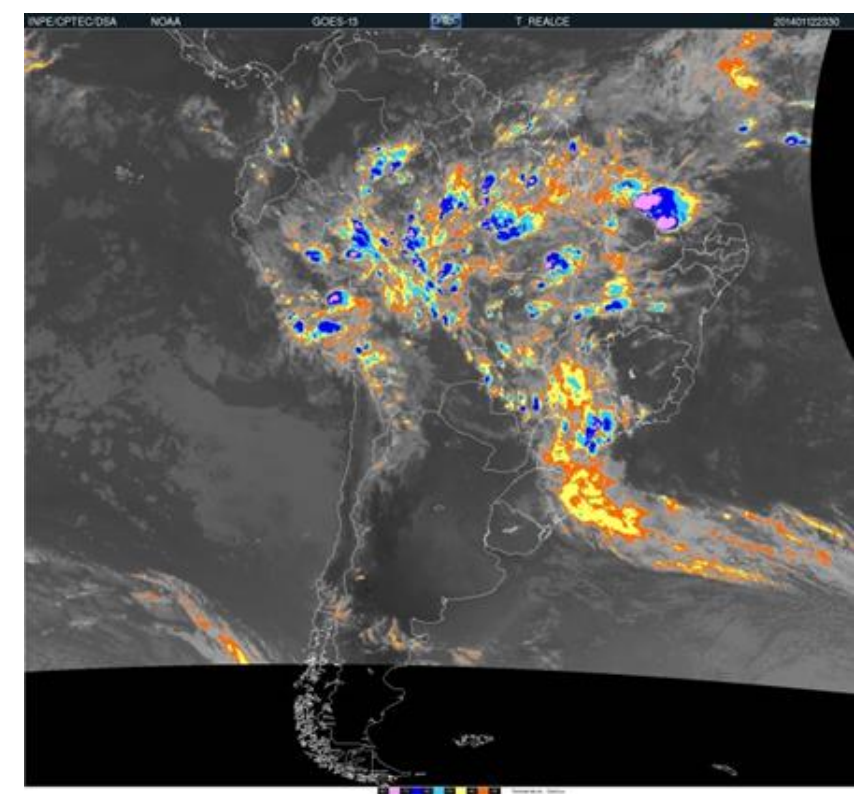

Figura 6 - Imagem Goes no momento do evento - condições meteorológicas da área

Os deslizamentos se sucederam em setores tanto definidos como preservados, áreas de encosta, encostas elevadas (Figura 08) resultando na rápida saturação do solo e no carreamento de detritos como solo, rochas e árvores, ocasionando, consequentemente, um processo de erosão lateral e também do leito dos rios Palmital e Funil. Os detritos percolaram de vários pontos, em um misto de lama, galhos, árvores e rochas que acabaram por atingir o bairro Guarda-Mão de forma mais direta, e indiretamente o restante do município. 

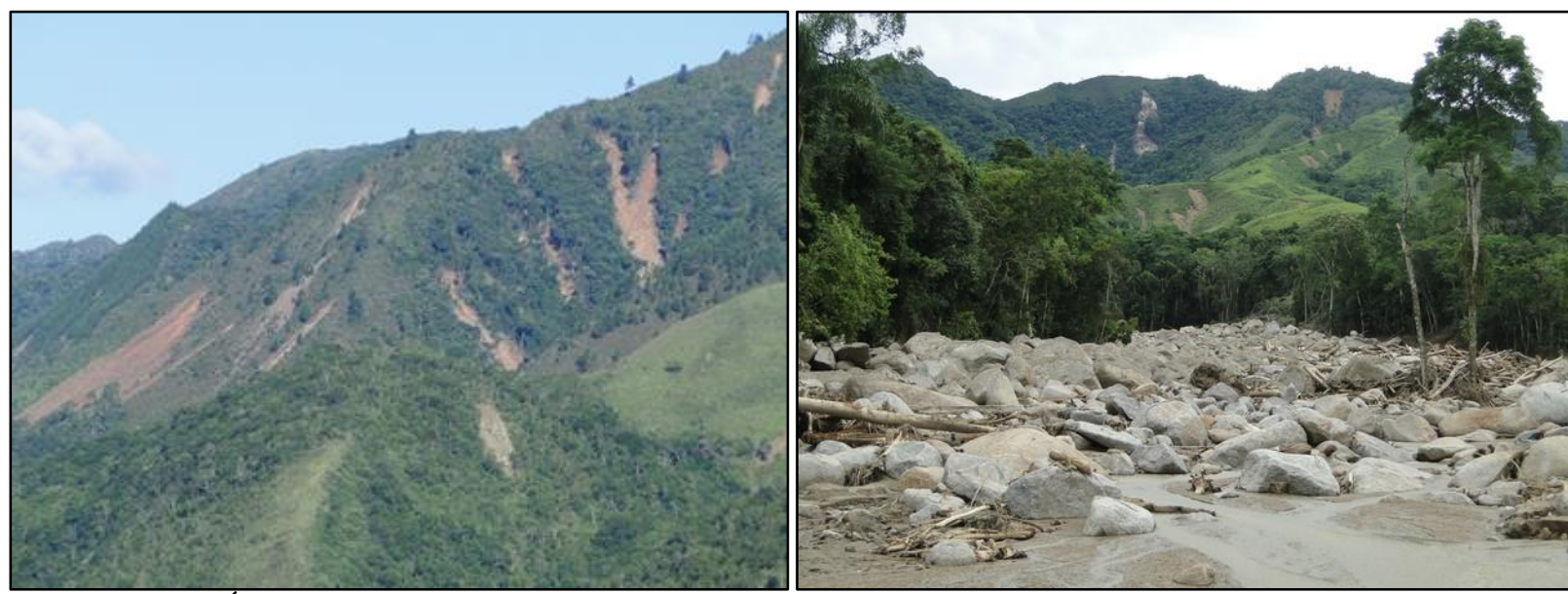

Figura 7 e 8- Área do Bairro Guarda-Mão. Ao fundo, as cicatrizes nas encostas do morro, Itaoca-SP. Encosta após deslizamentos e corrida de detritos

Fonte: Site de Notícias G1 (http://g1.globo.com/sp/santos-regiao/noticia/2014/01/itaoca-tenta-ressurgir-dascinzas-apos-onda-que-devastou-cidade.html)

Em conformidade com o artigo elaborado pelo Instituto de Pesquisas Tecnológicas do Estado de São Paulo (IPT), o geólogo Marcelo Gramani relata que a bacia do Ribeirão GuardaMão, local onde houve a maior concentração de vítimas, tem uma área de $7 \mathrm{~km}^{2}$ e uma extensão de $4 \mathrm{~km}$, apresentando um desnível de $800 \mathrm{~m}$ até atingir o Rio Palmital. A precipitação registrada em seis horas soma um total de $150 \mathrm{~mm}$, sendo o total acumulado de $24 \mathrm{~h}$ um somatório que ultrapassa os $200 \mathrm{~mm}$.

A soma dos elementos pluviosidade concentrada, saturação do solo e áreas de alta declividade resultaram na ocorrência de uma enxurrada gerada por um evento denominado de “corrida de detritos", com a montante da área urbana que carreou para o corpo hídrico uma grande quantidade de materiais, tais como solo, pedras, galhos, árvores, que ao adentrarem o rio Palmital atingiram uma alta velocidade. Ainda houve, aliado a isso, o extravasamento do leito em virtude das chuvas que antecederam o evento.

O município de Itaoca possui uma característica que o categoriza como área de risco. Tal fato se deve em virtude da localização da malha urbana, tendo em vista o leito do Rio Palmital, afluente do Rio Ribeira do Iguape, pois este corpo hídrico corta a área urbana em sentido lestenoroeste e é cenário de constantes eventos de inundações e enxurradas, as quais são consequências de grandes eventos pluviométricos, concentrados, principalmente, no período do verão.

O vale do Ribeira já registrou seis grandes eventos hidrometeorológicos de grande magnitude:em 1954 (maio), 1983 (maio), 1995 (jan.), 1997 (jan.) - conhecida como a enchente do século, devido a sua magnitude e tempo de permanência-, 1998 (fev.-mar.) e 2011 (jul.-ago.). As manchas de inundação referentes aos anos de 1995, 1997 e 1998 seguem representadas a seguir, e através de sua observação podemos inferir o enorme impacto sobre a área urbana de Itaoca, não 
ficando restrito a este município, tendo em vista que grande parte dos municípios do Vale do Ribeira constituíram suas áreas urbanas ao longo do curso dos rios.

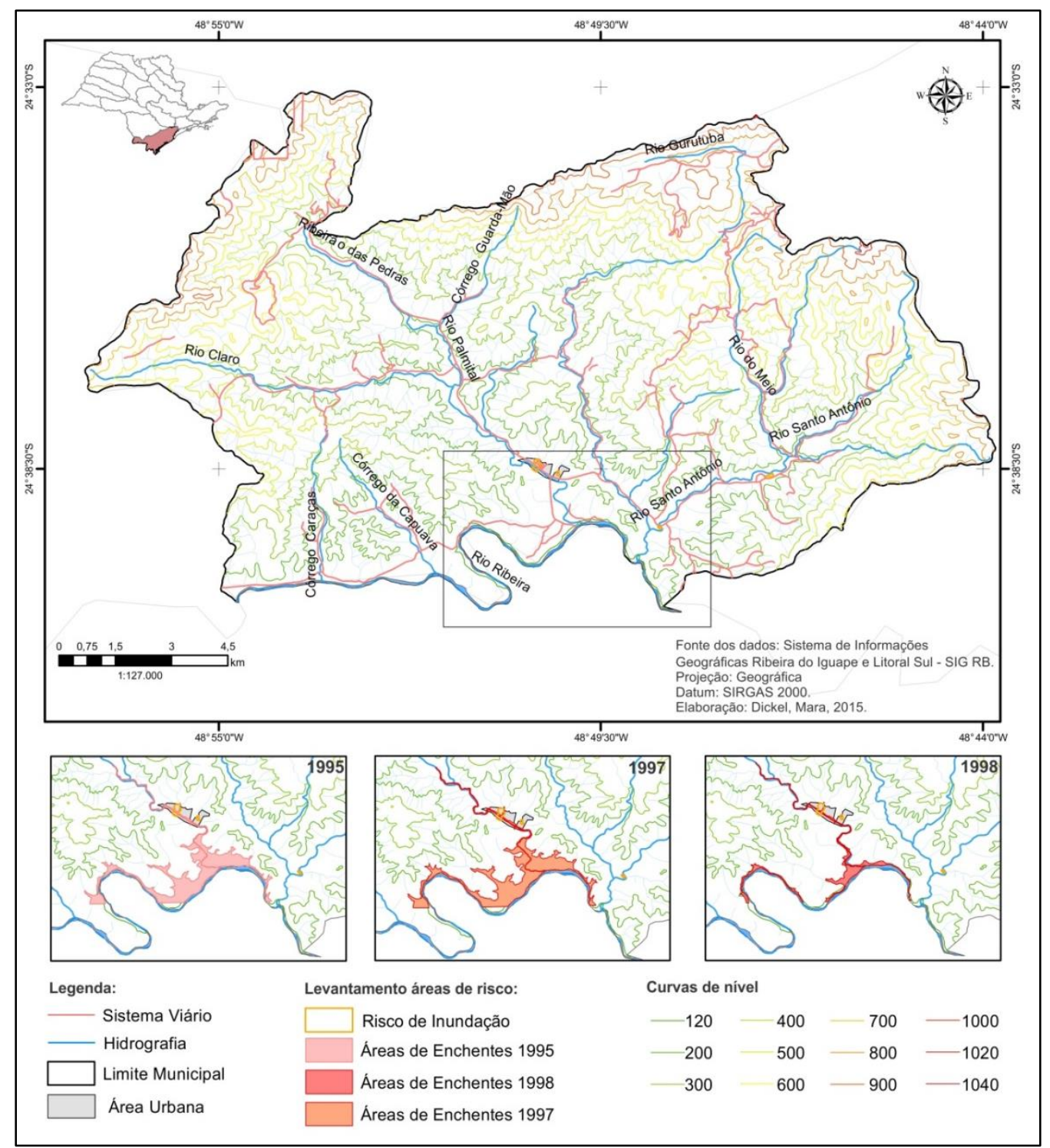

Figura 9 - Município de Itaoca Organizado pelo autor (2015)

O cartograma apresentado na Figura 10 representa o município de Itaoca, suas características básicas e as manchas de inundação referentes aos anos 1995, 1997 e 1998. Percebe-se que, no ano de 1997, a inundação atingiu a maior cota (aproximadamente 180m), resultando em 231 desabrigados e uma morte no município. No Vale do Ribeira, conforme dados da Coordenadoria Estadual de Defesa Civil, 15.440 desabrigados e três óbitos foram registrados, sem um em Itaoca e dois em Eldorado, além dos impactos enormes nas atividades agrícolas, serviços essenciais e vias de acesso aos municípios.

O evento de janeiro de 2014 foi resultado de escorregamentos de detritos que devem ser entendidos como movimentos rápidos de partes do terreno constituídos por solos e rochas. Dentro 
desta perspectiva, tem-se também a definição do evento desastroso ocorrido em Itaoca, entendido como corrida de detritos.

movimento semelhante ao de um líquido viscoso ou fluido, de velocidade média a alta, de grande volume de material (solo, rochas, detritos e água), com desenvolvimento ao longo dos cursos de água. Tem extenso alcance, mesmo em áreas planas, e grande poder de destruição, pois devasta tudo que está em seu trajeto. (VEDOVELLO, MACEDO p.30)

Desta forma, questionam-se as ações de monitoramento e alerta de risco e desastre, pois o evento em questão, ocorrido em Itaoca, foi o resultado de um somatório de eventos, maiores concentrações pluviométricas em áreas de cabeceiras de drenagem, alta pluviosidade acumulada aliada à questão da existência de áreas urbanas próximas ao do leito do rio, neste caso, o Rio Palmital, o qual atravessa a área urbana de Itaoca. E este fato não é diferente em outros municípios da região, pois o Vale do Ribeira é reflexo do processo de ocupação orientado pela atividade mineradora; desta forma, grande parte das cidades constituíram-se às margens dos rios.
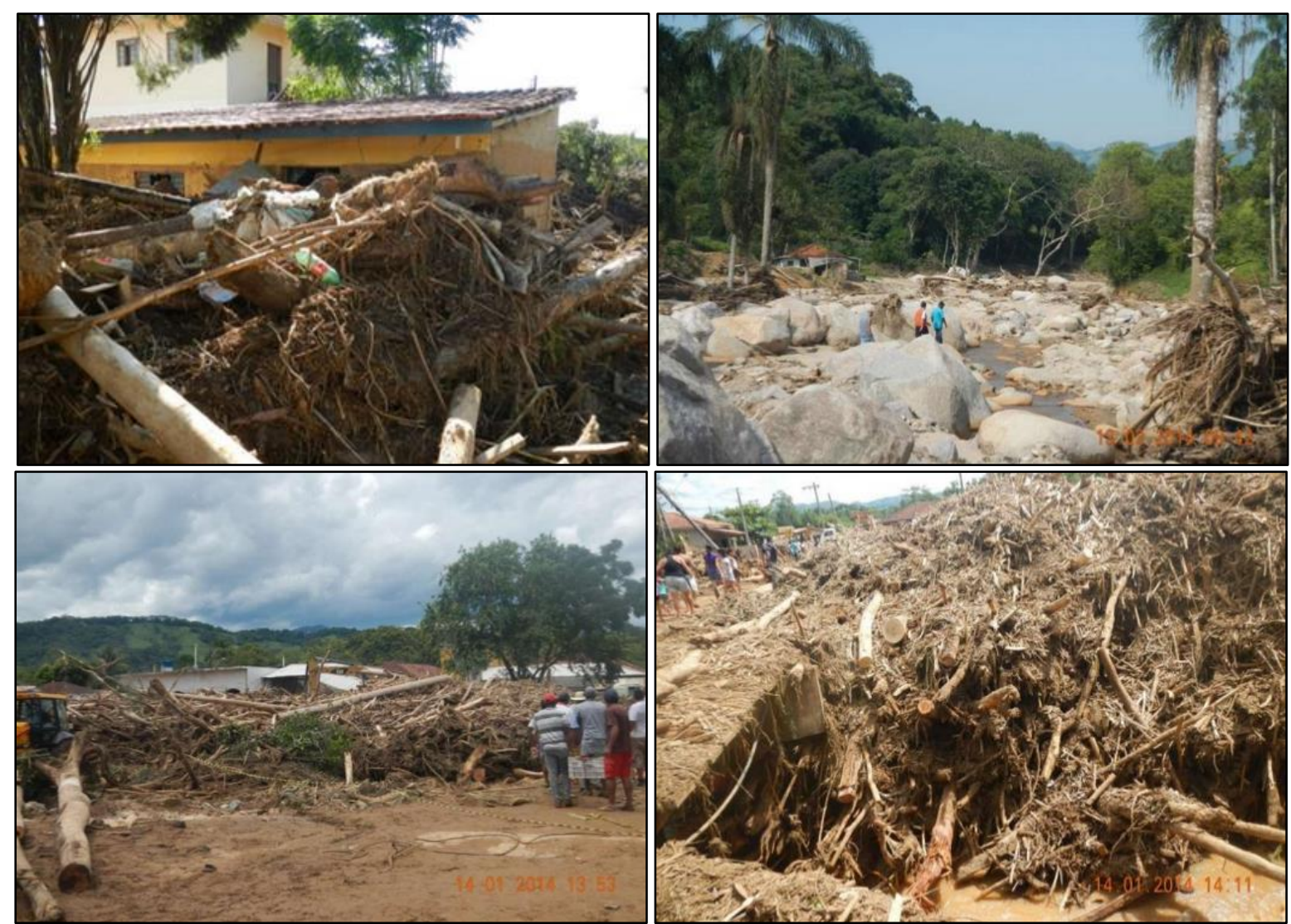

Figura 10 - Imagens da cidade pós-evento

Fonte: Site de Noticias G1 (http://g1.globo.com/sp/santos-regiao/noticia/2014/01/itaoca-tenta-ressurgir-dascinzas-apos-onda-que-devastou-cidade.html)

Diante desse contexto, o Comitê de Bacias, na forma do Comitê de Bacias Hidrográficas do Ribeira do Iguape e Litoral Sul, em parceria com a Defesa Civil, realiza levantamentos e análises objetivando identificar áreas vulneráveis e de risco nas cidades que compõem a sua Bacia. No 
município de Itaoca, tecnicamente foram registrados quatro pontos potenciais para a inundação, sendo dois especificamente localizados na área urbana, local onde se concentram a maior quantidade de pessoas atingidas com o evento ocorrido em janeiro de 2014.

A análise de riscos ambientais, tomando por referência a bacia hidrográfica, tem uma característica bastante peculiar, pois, embora seja uma área com limites definidos, internamente apresenta um cenário extremamente diverso e dinâmico, contexto esse resultante dos usos múltiplos do solo e da água, elemento chave desse sistema. A partir do entendimento da dinâmica que rege o funcionamento da bacia, os riscos podem ser identificados, analisados e classificados oportunizando a construção de embasamento científico para a elaboração de medidas mitigadoras em prol da retomada do equilíbrio e dinamicidade da bacia, através da entrada e da saída de matéria e energia.

\section{CONSIDERAÇÕES FINAIS}

As análises apresentadas remetem a algumas questões que merecem destaque. A questão de riscos e desastres não é recente, pois seus delineamentos são resultantes das inquietações provocadas por estes problemas que são, por sua vez, produto da interação entre elementos naturais (geologia, geomorfologia, elementos climáticos, precipitação, vegetação) e elementos antrópicos, sendo estes delimitados enquanto há interação do homem com o meio, na sua apropriação e uso do espaço.

A apropriação e a alteração das características naturais do espaço interferem na dinâmica da paisagem. Desta forma, ao tratarmos da questão riscos e desastres ambientais relacionados à questão recursos hídricos, como inundações e enchentes, torna-se essencial a realização de uma análise pautada em uma visão ampla, sistêmica e complexa, realizada através da adoção da Bacia Hidrográfica como unidade de análise.

\section{Agradecimentos}

Desenvolvido com recursos CNPQ. 


\section{REFERENCIAS}

ALMEIDA, L. Q. D. E. Riscos ambientais e vulnerabilidades nas cidades brasileiras: conceitos, metodologias e aplicações. São Paulo: Cultura Acadêmica, 2012. p. 215

BECK, U. Sociedade de risco: rumo a uma outra modernidade. Tradução de Sebastião Nascimento. São Paulo: Ed. 34, 2010. 368 p.

BRASIL. Lei $\mathbf{n}^{\mathbf{0}}$ 9.433/1997, de 8 de janeiro de 1997. Institui a Política Nacional de Recursos Hídricos, cria o Sistema Nacional de Recursos Hídricos e dá outras providências. Diário Oficial da União, Brasília, DF, 1997

BRASIL. Lei $\mathbf{n}^{\mathbf{0}}$ 12608, de 10 de janeiro de 2012. Institui a Política Nacional de Proteção e Defesa Civil - PNPDEC; dispõe sobre o Sistema Nacional de Proteção e Defesa Civil - SINPDEC e o Conselho Nacional de Proteção e Defesa Civil - CONPDEC; autor. Lei N ${ }^{\circ} 12.608$, de 10 de Abril de 2012. 1. ed. Disponível em: <http://www.planalto.gov.br/ccivil_03/_Ato20112014/2012/Lei/L12608.htm>. Acesso em: 10 ago. 2014.

BRASIL.Ministério da Integração Nacional. Anuário Brasileiro de Desastres Naturais 2013. Brasília: Centro Nacional de Gerenciamento de Riscos e Desastres (CENAD), 2013.

BURTON, I.; KATES, R. W.; WHITE, G.F. The Environment as Hazard. New York: Oxford University Press, 1974.

CASTRO, C.M.; PEIXOTO, M. N. O.; RIO, G. A. P. Riscos ambientais e geografia: conceituações, abordagens e escalas. Anu. Inst. Geocienc., Rio de Janeiro, v. 28, n. 2, 2005 . Disponível em <http://ppegeo.igc.usp.br/scielo.php?script=sci_arttext\&pid=S0101-

$97592005000200002 \& \operatorname{lng}=$ pt\&nrm=iso>. acesso em 10 nov. 2014

CASTRO, S. D. A. Riesgos y peligros: una visión desde lá Geografía. Scripta Nova: Revista Electrónica de Geografía y Ciencias Sociales. Barcelona, n.60, 15 de mar. 2000. Em: http://www.ub.es/ geocrit/sn-60.htm .

CEPED - UFSC, CENTRO UNIVERSITÁRIO DE ESTUDOS E PESQUISAS SOBRE DESASTRES (Santa Catarina). Universidade Federal de Santa Catarina. Atlas brasileiro de desastres naturais 1991 a 2010: volume Brasil. Florianópolis: Ceped Ufsc, 2012. 91 p. Disponível em: <http://www.ceped.ufsc.br/biblioteca/projetos/encerrados/atlas-brasileiro-de-desastresnaturais $>$. Acesso em: 6 jun. 2014.

CHRISTOFOLETTI, A. Modelagem de Sistemas Ambientais. São Paulo: Edgard Blücher, 1999. $256 \mathrm{p}$.

COMITÊ DA BACIA HIDROGRÁFICA DO RIO RIBEIRA DE IGUAPE CBH - RB 2. Comitê da Bacia Hidrográfica Ribeira do Iguape e Litoral Sul. 2008. Relatório da Situação dos Recursos Hídricos da UGRHI-11. 2008 Disponível em http://www.sigrb.com.br. Acesso em 22/09/2014.

COMITÊ DA BACIA HIDROGRÁFICA DO RIO RIBEIRA DE IGUAPE CBH - RB 2. Comitê da Bacia Hidrográfica Ribeira do Iguape e Litoral Sul. 2012. Relatório da Situação dos Recursos Hídricos da UGRHI-11. 2012. Disponível em http://www.sigrb.com.br. Acesso em 27/09/2014.

COMITÊ DA BACIA HIDROGRÁFICA DO RIO RIBEIRA DE IGUAPE CBH - RB 2. Comitê da Bacia Hidrográfica Ribeira do Iguape e Litoral Sul CBH - RB. Relatório Técnico Final 2012. 
Comitê da Bacia do Hidrográfica do Ribeira de Iguape. Disponível em: www.sigrh.sp.gov.br. Acessado em setembro de 2007

CUNHA, L. H; COELHO, M. C. N. Politica e gestão ambiental. In CUNHA, S. B.; GUERRA, A. J. T. (org). A questão ambiental: diferentes abordagens. Rio de Janeiro: Bertrand Brasil, 2003.

CUNHA, S. B. Canais fluviais e a questão ambiental. In CUNHA, S. B.; GUERRA, A. J. T. (org). A questão ambiental: diferentes abordagens. Rio de Janeiro: Bertrand Brasil, 2003.

CUNHA, S. B.; GUERRA, A. J.T. (Org.). Impactos ambientais urbanos no Brasil. Rio de Janeiro/RJ: Bertrand, 2003.

DAEE (DEPARTAMENTO ESTADUAL DE ÁGUAS E ENERGIA ELÉTRICA). 2002. Relatório de Situação dos Recursos Hídricos do Estado de São Paulo - Plano Estadual de Recursos Hídricos. São Paulo: DAEE, 119 p.

MAREngo, J. et al. Atlas de Cenários Climáticos Futuros para o Brasil - Projeções climáticas (precipitação e temperatura) para o Brasil durante a segunda metade do Século XXI usando modelos regionais, nos cenários de baixas emissões (otimista IPCC-B2) e de altas emissões (p. v. 1, p. 124, 2007.

MAURO, C. A. de; PINTO, B. M. S. Aspectos do Meio Ambiente Urbano. Boletim de Geografia Teorética. Vol. 21, no. 42, 1991, 88-95.

MONTEIRO, C. A de F. Teoria e Clima Urbano. In: MONTEIRO, C. A de F.; MENDONÇA, F. Clima Urbano. São Paulo: Contexto, 2003

NARVÁEZ L., LAVELL, A., ORTEGA, G.P. La gestión del riesgo de desastres: un enfoque basado en procesos. San Isidro: Secretaría General de la Comunidad Andina; 2009.

PORTO, M. F. A. e PORTO, R. L. L. Gestão de bacias hidrográficas. Estudos Avançados, São Paulo, v.22, n.63, 2008. p.43-60.

REBELO, F. Uma experiência européia em riscos naturais. Coimbra: Minerva Coimbra, 2005.

ROSS, J. L. S. 2002. A morfogênese da bacia do rio Ribeira do Iguape e os sistemas ambientais. GEOUSP - espaço e tempo. $n^{\circ}$ 12. São Paulo. 2002. p 21- 26

SANTOS, R. F. dos. Planejamento ambiental: teoria e prática. São Paulo: Oficina de Textos, 2004. 184 p.

TUCCI C. E. M. Gestão de inundações urbanas. Porto Alegre: Ministério das Cidades, 2005.

TUCCI, C. E. M.; BRAGA, B. Clima e Recursos Hídricos. In: TUCCI, C. E. M.; BRAGA, B. Clima e Recursos Hídricos no Brasil. Porto Alegre: ABRH, 2003.

TUCCI, C. E. M. Hidrologia: ciência e educação. 2. ed. Porto Alegre: Abrh, 1997. 944 p..

TUCCI, C. E. M.; MENDES, C. A. Avaliação Ambiental Integrada de Bacia Hidrográfica. 2. ed. Brasília: MMA, 2006. 302 p.

UN/ISDR. Marco de acción de Hyogo para 2005-2015: aumento de la resiliência de las naciones y las comunidades ante los desastres. Extrato del Informe de la Conferencia Mundial sobre la Reducción de los Desastres. 
UNDP - UNITED NATIONS DEVELOPMENT PROGRAMME. Reducing disaster risk: a challenge for development. New York, USA: UNDP, 2004. 129 p.

VEDOVELlO, R.; MACEDO, E. Deslizamentos de encostas. In: SANTOS, R. F. dos (org.). Vulnerabilidade ambiental: desastres naturais ou fenômenos induzidos? Brasília, Ministério do Meio Ambiente - MMA, 2012.

VEYRET, Y. RICHEMOND, N. M.. O Risco, os riscos. In: VEYRET, Y. (Org.) - Os Riscos - o Homem como agressor e vítima do meio ambiente. São Paulo: Contexto, pp. 23-79. 2007 